\title{
Pre-Service Teachers' Belief Sources about Learning and Teaching: An Exploration with the Consideration of the Educational Programme Nature
}

\author{
Emre Debreli ${ }^{1}$ \\ ${ }^{1}$ Dr. Fazil Kucuk Faculty of Education, European University of Lefke, Gemikonagi, Turkey \\ Correspondence: Emre Debreli, Dr. Fazil Kucuk Faculty of Education, European University of Lefke, \\ Gemikonagi, Mersin 10, Turkey. Tel: 90-392-660-2660. E-mail: edebreli@eul.edu.tr
}

Received: January 6, 2016

Accepted: January 20, 2016

Online Published: January 26, 2016

doi:10.5539/hes.v6n1p116

URL: http://dx.doi.org/10.5539/hes.v6n1p116

\begin{abstract}
It is often said that beliefs determine the ways teachers think and act in classrooms. There is now strong evidence that teachers' beliefs are formed during their previous education as students, and that they exert a powerful influence throughout their careers. However, only little has yet been done on the teacher education programmes' influence on teachers' beliefs, especially by taking the programme nature into consideration. The present study attempted to explore whether it is the previous learning experiences or the teacher education programme that influenced teachers' belief formation. Data were collected from sixteen ELT pre-service teachers in a university in Northern Cyprus through semi-structured interviews. Findings revealed that programme nature had a significant influence on pre-service teachers' belief formation compared to the influence of their previous learning experiences. Other sources of beliefs were also identified. Implications for teacher education are discussed.
\end{abstract}

Keywords: beliefs, pre-service teacher, apprenticeship, teacher beliefs, teacher education

\section{Introduction}

"Teacher beliefs" is an important area of research related to the field teacher cognition. As the term "teacher beliefs" implies, what goes on in teachers' minds is often acknowledged as their beliefs. Research carried out to date has revealed that beliefs strongly influence teachers' perception, and that they play a crucial role in teachers' decision-making, planning and implementation processes (Busch, 2010). Furthermore, there is evidence that they strongly guide teachers' classroom behaviour (Borg, 2006). Consequently, how teachers teach (approaches they adopt, activities they choose, materials they use, their relationships with the students, and so on) - is to a great extent, determined by their beliefs. Teachers with traditional beliefs for example, are said to be more likely to employ traditional (didactic) approaches to teaching whereas teachers with communicative beliefs are more likely to employ student-centred (non-didactic) approaches (Isikoglu, Basturk, \& Karaca, 2009). It is perhaps for this reason that the area "teacher beliefs" has gained a considerable amount of interest within the last two decades, and many work have been conducted on teachers' pre-existing beliefs. One strand of this work has primarily focused on the sources of teachers' beliefs, and there is now a popular perception that teachers' beliefs are to a great extent formed as a result of their previous learning experiences as students (Borg, 2003). Although there are also a variety of other sources proposed by many (i.e., Crookes, 1997), previous learning experiences is often taken for granted as a major source, despite other particular contextual elements have not been seriously explored. In the present study, it was of interest to understand in the present particular context whether the previous learning experiences of the teachers was the main source that guided teachers' beliefs, or whether it was the teacher education programme that determined teachers' beliefs, by taking the programme nature into consideration, which is something often neglected (Zheng, 2012). Other possible factors which might stood as source of beliefs were also explored.

\section{1 "Apprenticeship of Observation"}

Apprenticeship of observation (Lortie, 1975) is a term often used to refer to teachers' language learning experiences as students when they spent thousands of hours in classrooms for their own education. Many agree that apprenticeship of observation stands to be the most influential belief source. There is now convincing 
evidence that during their years as students, teachers form well established beliefs about language teaching/learning, teacher behaviour, teacher roles, good/bad teachers, what a classroom should be like, which methods, approaches and techniques are the most effective when teaching, how a language should be taught/learnt and many other issues relating to the teaching and learning process (Borg, 2006; Mattheoudakis, 2007; Peacock, 2001). Erkmen (2010, p. 23) further mentions that during the period of apprenticeship of observation, students are likely to form "anti- and pro- role models" of teachers and they decide which teacher role or character to adopt in the future. According to Lortie (1975), years spent as students involve massive hours of observation, and he characterizes this process as: "being a student is like serving apprenticeship in teaching; students have protracted face-to-face and consequential interactions with established teachers" (p. 61). Concurring with Lortie's view, studies in mainstream research indicate that apprenticeship of observation forms a large part of teachers' previously acquired beliefs (Borg, 2003; Busch, 2010; Farrell, 1999; Ng, Nicholas, \& Williams, 2010). The majority of them also reveal that the beliefs derived during such apprenticeship powerfully influence teachers' understanding when they attend teacher training programmes (Brown \& McGannon, 1998; Mansfield \& Volet, 2010).

Studies conducted on the sources of teachers' beliefs in the area of ESL (English as a Second Language) and in various TESOL (Teaching English to Speakers of Other Languages) programmes indicate very similar findings. Studies particularly on pre-service teachers participating in TESOL programmes indicate that the pre-service teachers' beliefs about teaching and learning are rooted in their own language learning experiences as students (Brown \& McGannon, 1998; Lihua, 2010; Numrich, 1996; Peacock, 2001; Urmston, 2003; Warford \& Reeves, 2003). Similarly, Peacock's (2001), Brown and McGannon's (1998) studies noted that pre-service teachers carried various beliefs to the training programmes from their previous learning experiences, and that these beliefs often reflected what they liked or did not like in their previous education. The researchers concluded that their previous beliefs affected their conceptualisation of the training programme. The impact of apprenticeship of observation can also be seen in the field of EFL (English as a Foreign Language). Similarly to the findings in mainstream research and in ESL, studies in the field of foreign language teaching indicate that non-native teachers' beliefs are mostly acquired during the period of apprenticeship of observation, and that their beliefs exert a powerful influence on how they perceive teaching and learning (Allen, 2002; Farrell, 2001; Yang, 2000).

\subsection{Other Sources of Beliefs}

In the area of teacher cognition on language teaching, there are also various types of sources or factors which are mentioned to influence teachers' beliefs, or where teachers derive their beliefs from. Researchers Borg (2006), Richards and Lockhart (1996) and Crookes (1997) are the ones who explicitly dealt with this issue and who provided frameworks on where pre-service teachers often derive their beliefs from or how they form their beliefs. Richards and Lockhart (1996), for example, discuss that experience of teaching, personality factors, educationally-based or research-based principles, and principles derived from an approach or method are also influential in teachers' belief formation and development. Curricula of the institution teachers teach at, exposure to new ideas, culture of teaching, types of learners teachers are teaching, and receiving feedback from the authorities are also other important factors which Crookes (1997) suggest as influencing beliefs. Although the influence of teacher training programmes is the subject of an ongoing debate (Johnson \& Golombek, 2003; Korthagen, 2010), there are studies which point out that teacher education can also be a belief source, but research on this aspect often focuses on the other side of the coin; that is, whether teacher education is able to influence the already existing beliefs of the teachers (Borg, 1998; Cabaroglu \& Roberts, 2000; Da Silva, 2005; Mattheoudakis, 2007), but neglects whether teacher education itself is a belief source.

With the intention of understanding the influence of teacher education on the formation of beliefs, the main study explored and tracked the beliefs of twelve final year pre-service teachers who were enrolled in a pre-service teacher-training programme over a course of nine-months in the ELT Department of a Turkish university in Northern Cyprus, after completing three years of theoretical input. Throughout the study, pre-service teachers' beliefs about learning and teaching, the relationship between their beliefs and what they had been taught in the modules of the ELT programme in the earlier years, change/development in their beliefs when confronted with the reality of practice and the ways in which their beliefs change/develop were considered. However, this particular paper only focuses on the influence of the present teacher education programme on the formation of teachers' beliefs; that is, whether the first three years spent in the programme caused student teachers to form beliefs. 


\section{Method}

The presented study adopted a qualitative methodology to investigate the phenomenon.

\subsection{Research Questions}

Of the several questions addressed in the main study, the following research question was explored in the present study:

- To what extent does the theoretical input received in the earlier years of the ELT programme influence pre-service teachers' initial beliefs (at the beginning of the practical phase of the training programme) about learning and teaching?

\subsection{Setting}

The ELT programme that this study was carried out in one of the universities in Northern Cyprus is a four year full-time programme. The aim of the programme is to train student teachers to teach at secondary schools after they graduate. Within the first three years of the programme, students take various courses on a theoretical basis, and in the final year, they attend practice teaching, which is the only practical opportunity they are exposed to within the duration of the programme. Within the first three years, students do not get exposed to the practical side of teaching, but extensively review various theories of English language teaching. In this regard, it can be said that there is a strong gap between theory and practice in the present ELT programme. In the final year of the programme, student teachers attend practice teaching, which require them to conduct observations of actual classrooms in state schools for limited hours (six hours), as well as to teach at the same state schools for four hours.

\subsection{Participants}

The study was carried out with 12 pre-service teachers in total, with a mix of genders of seven females and five males. Their ages were between 20 and 23 . The majority of the pre-service teachers were originally Turkish Cypriots and one of them was originally from Turkey. They had all been studying in the ELT Department for three years and had recently moved to their final year of studies by the time the present study began. During these years of education, all the pre-service teachers had taken the same modules within the department. The pre-service teachers in this study had different educational backgrounds. Six out of twelve had completed their secondary education in private colleges, whereas five out of twelve had attended government schools in Northern Cyprus. They had all been exposed to the English language since their primary or secondary education.

The pre-service teachers' teaching experience was considered to be scant. This argument was also confirmed by each pre-service teacher during the interviews. They all stated that they had not had any previous formal teaching experience nor had they been in real classrooms as a teacher or as an observer by the time this study began. However, they had carried out micro-teaching (15-minute) sessions delivered to their classmates during their third year in the ELT Department. When they were asked if they believed or felt whether those micro-teaching sessions had facilitated their conceptions of teaching and learning, seven pre-service teachers stated that they did not feel it was a real experience as they delivered these sessions to their classmates.

\subsection{Data Collection Methods}

In line with the qualitative research design adopted, semi-structured interviews and diaries were used as data collection instruments in the main study. The reasons for selecting these instruments lied behind the fact that beliefs can be best explored via conversational instruments, and instruments that prompt reflection (Phipps \& Borg, 2009). Such investigation was believed to help obtaining a detailed and more fine-grained picture of the possibly smaller number of categories that arose from the data, and to track them, rather than exploring a wider range of pre-determined categories or issues more superficially. However, for this particular paper, only the interview instrument is explored, as the aim of the diaries was different in the main study.

\subsubsection{Semi-Structured Interviews}

To elucidate answers for the research question posed, it was believed that a conversational tool was needed to facilitate a question-answer-question process (Borg, 2006; Patton, 2002). Since the most important aspect of this study was to obtain a sufficiently rich body of data to develop good understanding of the overall picture, the semi-structured interview was one of the most reliable instruments to meet this objective by offering the researcher the opportunity to immediately follow-up on any points that arose in interviews to elicit further and more in-depth information or clarification. Another reason for using interviews was to reveal what the participants actually have in their minds that could not be elicited through other instruments.

The interviews were conducted at the beginning of the training programme, and first aimed to elicit information 
about the teachers' educational background, age, nationality, teaching experience, duration of exposure to the English language and the reasons why pre-service teachers chose to study ELT as a profession. The reasons for exploring these was to be able to make sense of whether any background features such as the previous schools pre-service teachers had attended had an influence on their beliefs (this was also supported with some follow-up questions during the interviews). The rest of the questions asked in the interviews were mainly focused on issues related to language learning and teaching, followed by questions which would reveal whether their beliefs were influenced by the theories presented in the ELT programme. To elicit such information, headings were drawn up of themes to be explored in the interviews that would provide such information. These themes were then explored in each interview, with questions based on them and worded flexibly according to the progression of the interview (i.e., a predetermined set of questions was not used, and the wording/order of questions posed varied). During the interviews, each pre-service teacher was asked questions about specific themes (e.g., questions about characteristics of effective teachers). They were also asked questions which would bring them back to their own experiences by asking about the teachers they themselves had had.

\subsection{Data Analysis}

Data analysis involved transcription of the audio-recorded interview data, followed by familiarization after repeated reading sessions. This process was then preceded by dividing the large data chunks into discrete parts (Miles \& Huberman, 1994) and assigning codes to them. The codes were then checked for their reoccurrence and the codes that went together were collected under one theme, which formed categories (ibid.). During the analysis, four main categories, namely as: theories presented in the earlier years of the ELT programme, previous learning experiences, self, and general knowledge emerged (see Section 3 for more details).

\section{Findings}

Throughout this section, information about the theoretical input's influence on beliefs, as well as the influence of other factors on beliefs are presented with reference to the excerpts and examples from the interviews. In order to identify the influence of all these factors, pre-service teachers were asked some follow-up questions and further probed according to the answers they gave to the interview questions asked. For example, when a pre-service teacher said that he/she believed X, or when it was inferred from the explanations he/she gave whether he/she believed X, he/she was further asked questions such as: What makes you think like that? How do you know that? Where did you get this idea? The answers given to these questions helped to reveal the influence of theoretical input received in the earlier years of the programme, as well as other factors that shaped/influenced their beliefs. Analysis of the data revealed that the factors influencing pre-service teachers' beliefs about learning and teaching were varied, but that the theoretical input received in the earlier years was the most influential factor of all. In Table 1, the number of citations made by the pre-service teachers is given based on counting the instances of each category relating to different influences on beliefs. Pseudonyms are used throughout.

Table 1. Number of citations made by the pre-service teachers related to the belief source categories

\begin{tabular}{ll}
\hline Category & Number of citations \\
\hline Theories presented in the earlier years of the & 37 \\
ELT programme & \\
Previous learning experiences & 23 \\
Self & 12 \\
General knowledge & 8 \\
\hline
\end{tabular}

For example, when pre-service teachers said or indicated that they believed in the effectiveness of a specific language teaching method or technique because it was what they were taught in their lessons in the ELT programme, or it was what their teachers suggested they adopt, or it was what they read in the module course-books such responses were coded as "theories presented in the earlier years of the ELT programme", and the total number of such references counted. Similarly, when they said or implied that they wanted to be or did not want to be like one of their previous teachers, or when they described why they believed particular teaching methods or techniques were effective or not and why they preferred to adopt them or not, owing to their positive or negative learning experiences with those particular methods and techniques, these were considered as related to the "previous learning experiences" category and such responses were also counted to identify the number of links made to this category. 


\subsection{Theories Presented in the Earlier Years of the ELT Programme}

In the study, the beliefs derived from pre-service teachers' education in the earlier years of the ELT programme were found to be the most influential source. Here, the earlier years of the ELT programme was considered as including the theories with which pre-service teachers were presented in various modules they took, the information that they were exposed to in their module course-books, and the input they received from their module teachers.

The initial data suggested that the courses pre-service teachers took in the first years of the programme had a particular effect on forming the beliefs. These effects were clearly addressed by the pre-service teachers during the interviews, and Edward, William, Helen, Ruth, Charlotte and Paul, for example, talked at length about how they developed beliefs with regard to what they were given within those modules. Excerpts taken from the interviews with Ruth and Charlotte are provided below and they are illustrative of how these pre-service teachers regarded the modules provided by the ELT programme and how their beliefs about learning and teaching were shaped by them. Ruth, for example, commented:

Well, we attended various module sessions where we were provided with various alternative language teaching issues and the information presented in those sessions by our teachers was really useful in explaining which language teaching approach, method and technique actually works in which circumstances... For example, now, I am aware that explicit teaching strategies are somewhat limited in terms of their contribution to student learning because it is something like when a teacher transfers knowledge to the student and the student passively receives it. We have been taught that this should not be how students ought to learn but we need teaching approaches which encourage students to learn themselves by discovering.

Ruth Int. 1

As can be seen in the above excerpt, Ruth, rather than making her own reflections of which approach was better and why, directly gave what she had been taught in the earlier years of the ELT programme as a reference. Although she provided explanations about why, for example, explicit teaching strategies were limited, it may be said that such ideas were developed during the modules she previously attended, or what her teachers told her. Although there was still a possibility that these might be her own ideas, her continuous reference to "what she had been taught" in the ELT programme may indicate that these beliefs were derived from the information she was presented. She seems to view what she had been taught as the most accurate, and rather than commenting from her own perspective or making her own critique, she explained her beliefs by relying on the input she received in her modules.

Similarly to Ruth, when Charlotte was asked how she came to prefer to adopt CLT as an approach to teaching and how she knew that CLT was the most beneficial method, she said:

- I know because that is what we did throughout the previous year. The lessons we attended and our teachers always emphasised the benefits of CLT as a teaching approach and we did all the activities and practices within the classroom along the same lines as CLT. The information presented in those sessions by our teachers clearly showed us the benefits of adopting CLT as an approach to teaching and I became aware of how it [CLT] differs from other approaches and why it should be used.

\section{Charlotte Int. 1}

Here, Charlotte also makes strong references to her previous module input and to her teachers as suggesting CLT as the most beneficial method that should be used when teaching. Although she also said that her teachers taught her according to the principles of CLT, which can also be seen as related to her learning experience, the emphasis on the overall quote she provides seems to be on what she had been told to believe, rather than what she actually believed.

Helen and Paul also addressed how the methodology courses they attended prior to the training programme had influenced their beliefs about teaching. Helen, for example, commented that the language acquisition courses she completed had made a great contribution to her knowledge and that she became aware that she used to have a very old-fashioned approach to teaching, and after attending these courses, she reviewed and revised what she already knew. Similarly, Helen recalled her course experiences and mentioned that she became aware of the latest language teaching strategies when she learned about approaches in the ELT I and II modules. Paul also described how previous modules influenced his beliefs such as developing understanding of the variety of language teaching approaches and techniques and not sticking to specific language teaching approaches or techniques. All these statements may indicate that pre-service teachers in general developed beliefs from what modules in the ELT programme offered them, and what their module teachers suggested or told them, rather than 
from their personal experiences. This may not be unexpected, given the participants' lack of teaching experience on which to base their reflections, which perhaps meant that for them the course input became the most reliable source on which to base their beliefs.

\subsection{Previous Learning Experiences}

The initial data revealed that a considerable number of the beliefs pre-service teachers brought to the training programme were also established as a result of their previous learning experiences during their school years. Their responses illustrated how past learning experiences influenced how they viewed teachers, teaching and learning. The data indicated that these beliefs were formed according to the teacher characteristics which the pre-service teachers liked/disliked, the teachers whom they admired or viewed as role models, and the teaching approaches, methods and techniques with which they had been taught by and which they liked/disliked. All these factors seemed to affect pre-service teachers' beliefs about several aspects of the teaching and learning processes, as well as about the teachers. The sources of their beliefs related to previous learning experiences, however, were classified in two sub-categories (positive and negative learning experiences), as the data revealed that there was a considerable amount of information related to both these aspects.

\subsubsection{Positive Learning Experiences}

Pre-service teachers' positive learning experiences included information about the teachers they liked, how those teachers behaved in the classroom and how they taught. The following excerpts illustrate how the teachers and teaching approaches they liked influenced the teacher characteristics and the teaching approaches they themselves wanted to adopt when teaching and how they developed associated beliefs.

I used to have a great teacher who had wonderful relationships with all of us [students] and who cared about our opinions... She always helped us whenever we needed... For example, she used gestures very effectively and always managed to get our attention during the lessons... She was always enthusiastic when teaching... She is the one who gave me the idea of becoming an English teacher.

Ruth Int. 1

Here, Ruth describes how one of her previous teachers whom she liked affected her decision of becoming an English language teacher and explicitly lists some characteristics that made that teacher special for her. The key issue here is that, in addition to her explicit explanation of what she liked most about her previous teacher, when asked in the interviews to describe a good/effective teacher, Ruth cited similar characteristics making teachers good/effective. This might indicate how her previous teacher's characteristics which Ruth liked influenced her perception of a good/effective teacher, and she indirectly cited these characteristics when describing a good/effective teacher in her mind.

Similar to Ruth, when Marilyn was asked to describe a good/effective teacher, she cited the characteristics such as being caring, approaching the students in a sensitive manner and being good at managing the classroom. When further asked to describe a previous teacher whom she liked, she also cited the same characteristics about that teacher. This might suggest how her previous teacher's characteristics had an influence on what types of characteristics she wanted to have when teaching, as there were very close similarities between her previous teacher's characteristics and the characteristics she wanted to have.

\subsubsection{Negative Learning Experiences}

Pre-service teachers also referred to their previous negative learning experiences as students. These included the teachers and teacher characteristics they disliked, their bad experiences with regard to learning and teaching, and how those bad experiences influenced their beliefs about teachers, teaching and learning. The most frequently mentioned bad learning experience (Melissa, Helen, Albert, \& William) was that of teachers who made students feel humiliated and embarrassed in front of the whole class. Helen and Albert described those experiences, what they felt during those experiences and how they impacted on their beliefs. They said:

I hate teachers who make students feel embarrassed in front of everybody. I used to have one of those teachers and when he asked us questions, if we gave the wrong answer, he used to say "oh, really?", "you must have thought a lot to say this", "are you sure you want to do this course?" and he used to make us feel very bad and humiliated... I never wanted to participate in his lessons because of his bad behaviour and I never liked him. I will never be like him and I will always approach my students in a more caring way.

Helen Int. 1

As reflected in the above excerpt, Helen expresses a type of behaviour that her previous teacher used to have, which she did not like. She explains how such behaviour affected her progress during the lessons of that teacher, 
and as a result of such negative experience, it may be said that she preferred not to treat her students like her previous teacher did.

In addition to the teachers and teacher characteristics they disliked, pre-service teachers also criticised aspects of the teaching approaches their previous teachers adopted when teaching them. Edward, Helen and Ruth, for example, talked about the activities and exercises their previous teachers used when teaching grammar which made the lessons boring and dull in consequence. These pre-service teachers mentioned how such bad experiences had had a negative impact on their views about teaching and made them aware of which teaching activities they ought to do during the lessons and when teaching grammar lessons. Helen commented:

Most of my previous teachers used to pay great attention to teaching us grammar and they were always engaging us in grammar exercises or activities and this usually created very quiet lessons with no energy and willingness... I don't see anything attractive and anything purposeful in teaching grammar that much but I am sure it makes students feel bored... I accept that grammar teaching could be needed sometimes but I would definitely do this with more entertaining activities where students could be lively and be engaged in group works, not in mechanical drills.

\section{Helen Int. 1}

In the above excerpt, Helen describes how extensive focus given to teaching grammar to her by her previous teachers influenced her view of grammar teaching. It seems from the excerpt that rather than extensive focus on teaching grammar, she was not happy with how grammar was taught to her as she explicitly expresses her disappointment with the activities used when teaching grammar which caused classrooms to be boring. This is also clear in her final comments where she seems to develop the belief that the use of "more entertaining activities" would make grammar teaching more enjoyable. Although it is not clear what kinds of activities her previous teachers used when teaching grammar, it can be understood that these were activities based on individual work which required students to solve mechanical tasks, which Helen does not want to adopt when she teaches.

Pre-service teachers' past learning experiences showed how negative ones had been influential in the beliefs they developed and may have impacted on what kind of teachers they wanted to be and how they wanted to teach in the future. Usually, pre-service teachers developed beliefs as a reaction against their negative experiences related to teaching and learning, preferring to adopt the opposite behaviours, attitudes and teaching approaches of the ones they disliked.

\subsection{Self}

Data showed that a considerable number of the beliefs pre-service teachers held were derived from self that is, they simply believed in particular issues by giving examples from themselves. Edward, Paul, William, Dominick, Helen and Marilyn were the pre-service teachers who expressed self-developed beliefs. Edward, for example, who did not believe in the existence of language aptitude, said that he held this view because he did not have such an aptitude. He considered language learning as related to practice. He seemed to come to the conclusion of language aptitude's non-existence by considering himself as a learner who did not have it, and rejected this idea consequently. Similarly, William also cited a self-derived belief when discussing why students should be encouraged to communicate through the use of group and pair-work activities. William said:

W: Because they [activities such as group and pair-work] help students to talk to each other and they improve their communication skills. Students also like this.

R: How do you know that students like this?

W: Well you need to put yourself in students' shoes to understand this. I mean I like to be taught this way because I like it.

\section{William Int. 1}

As can be seen, because William himself likes to be taught through group and pair-work activities, he seems to perceive that every student likes to be taught this way, thus places emphasis on these activities.

Similarly to the above pre-service teachers, Marilyn also mentioned that she would definitely use praising in her classrooms, as this was something that would enhance her motivation if she were a student. These sources may also partly be seen as related to their personalities (Richards \& Lockhart, 1996). 


\subsection{General Knowledge}

Although not frequently mentioned, the discussion with the pre-service teachers also revealed that some of their beliefs were derived from their general knowledge or from the facts generally recognised as valid by the society. When discussing their beliefs about how teachers' good relationships with students could enhance learning, Helen and Paul, for example, commented that having a good relationship with a teacher was intrinsically effective in influencing learning or desire to learn. When Helen was asked how she knew that, she commented that it was something known by everyone and it just happened to be that way.

The following excerpt taken from the interview with Paul also suggests his source of belief was developed from general knowledge. Paul said:

P: When a student is motivated, you can clearly see how he/she is involved within the activities and within the process of learning that takes place in the classroom. You can feel the desire that student has towards learning and I am quite sure this is reflected in his/her achievements and grades...

\section{R: How do you know that?}

P: Well, I think you don't need to know that, I mean, I know it is this way but I can't explain it but it always seems like students are more likely to be successful when they are motivated... I think people would agree with me that motivated people are more likely to succeed...

Paul Int. 1

The above excerpt suggests that Paul's source of belief is somewhat linked to general knowledge and the generalisations he drew from his personal observations of certain situations. As explained at the beginning of this section, the sources of beliefs which were categorised as general knowledge were less frequently mentioned than the other categories of the sources which emerged. Helen, Albert and Paul were the only pre-service teachers who referred to the issues that could be categorised under general knowledge.

\subsection{Other Sources}

On some occasions, pre-service teachers also referred to other sources from which they had derived their beliefs. Since more than one pre-service teacher did not cite these sources, and such remarks were not frequent, they were not categorised separately. These sources were noted to derive from family, friends and teaching contexts. Charlotte, for example, whose mother was an English language teacher, believed that the best way to prevent student noise or misbehaviour during the classrooms was to ignore them until they stopped. When questioned how she knew that, she said it was what her mother had told her. Ruth, on the other hand, whose friend had recently graduated and started teaching in a school, believed that high school students were more likely to learn through oral activities rather than solving mechanical exercises such as multiple-choice or fill-in-the-gap. It was revealed that Ruth had derived this belief from what her teacher friend had told her about his own students. Marilyn, who was originally from Turkey and viewed grammar as the most important component of a language, was found to derive her belief from her previous context, as well as her previous education in Turkey. According to Marilyn, in Turkey, students expect teachers mainly to teach them grammar and it is accorded special attention during lessons. Although she became more flexible to the issue of adopting communicative approaches and placing less emphasis on grammar-based issues during her education in the ELT programme, she continued to believe that such approaches would not be easy to put in practice in Turkey. That being so, Marilyn's belief about adopting grammar-based approaches could be said to be the result of her original context's influence.

\section{Discussion and Conclusion}

These findings show that unlike the findings of the previous studies which reported previous learning experiences as the most influential belief source, the present study reports that the ELT programme was the strongest influence on pre-service teachers' beliefs. It is, however, important to mention that the sources of beliefs discussed throughout this section are mostly the ones that the participants were consciously aware of, or the ones that they articulated, perhaps as a result of the input received from their teachers, courses, textbooks, or discussed in any other components of the course (e.g., exams and essays). One should also acknowledge that these explicitly expressed beliefs might not represent participants' tacitly held beliefs, which are not yet articulated. In the study, the majority of these beliefs held seemed to be strongly influenced by the theories received in the earlier years of the ELT programme. This finding seems to contradict the findings of existing studies both in ESL and EFL, as well as in mainstream education, which often report previous learning experiences as the most influential source on teachers' beliefs (Mattheoudakis, 2007; Peacock, 2001), which is also often termed "the apprenticeship of observation". However, the influence of previous learning experiences and other sources such as beliefs derived from self and general knowledge also emerged in the data as 
influencing pre-service teachers' beliefs. On most occasions, the pre-service teachers referred to what they had learnt or been taught in the ELT programme in the first three years when explaining why they believed what they believed so, or why they preferred to adopt specific teaching approaches when teaching. When they were asked questions such as "How do you know that?" or "Where did you get this idea from?" they often responded with "This is what we have been taught here", "This is what our teachers suggest to us here" and "The course books we follow in our modules suggest this". Since there are only few studies indicating teacher education as a major source of belief formation/development, it is difficult to discuss this finding in relation to others. The study by Wong (2010), however, noted that the teacher education that Malaysian pre-service teachers received had a strong influence on the beliefs they held about adopting communicative approaches in EFL classrooms, similar to the finding emerging from the present study. Like the programme Wong (2010) studied, the present ELT programme also seems to educate its students in communicative and constructivist principles, and encourage them to adopt such approaches when they went into classrooms. In both contexts, the structure of the ELT programme seems similar, theory and practice being kept as separate entities and heavy emphasis being put on the theoretical aspects of language teaching and learning during the first years of the programme. Perhaps as a result of such a focus on theoretical aspects, pre-service teachers in the present study seem to hold beliefs that go along with communicative and constructivist principles, perhaps perceiving such input as the most accurate and reliable information. Although one may argue that the pre-service teachers in other programmes do not always accept such input, the limited content and the didactic nature of the overall ELT programme may have made these pre-service teachers more accepting.

In the present study, pre-service teachers seem to be evaluating their beliefs and preferences in the light of both theoretical and practical aspects. This, however, is something very limited (especially the practical perspective) in the present context, as they seem to be failing to do pedagogical reasoning. Ong'ondo and Borg (2011), for example, mention that such pedagogical reasoning "is essential because teaching is a complex process in which teachers must constantly take into account and make sense of often unpredictable and dynamic interrelationships among several variables including teacher, learners, the context, and the curriculum" (p. 510). Pre-service teachers in the present study, however, do not seem to be able to develop fully such pedagogical reasoning. The strong emphasis put on the theoretical aspects in the first years of the programme, an imbalance between theory and practice in the programme as a whole, and late exposure to practice seem to be some of the possible reasons behind pre-service teachers' under-developed pedagogical reasoning. It may be that the first three years of the ELT programme cause pre-service teachers to be passive knowledge receivers, as they do not seem to critically evaluate, or find opportunities to test the applicability of the information presented to them, and they perceive the information presented in the course as the most accurate and correct. This is also clear in some of their responses which sound as if they come straight from their course-books or what their teachers told them. This confidence and trust in the course input also seems to restrict pre-service teachers in recalling their past learning experiences or other sources of the beliefs they hold regarding teaching and learning, and the ELT programme for many becomes the major belief source. These can be explained by reference to the views of Feiman-Nemser (2010) who argues that if pre-service teachers are not given opportunities to transcend technical thinking about what to do in the classroom and to engage in trying to establish relevant connections between theory and practice, they should not be expected to be attentive to practice and to be critical of the experience of learning to teach. This, according to Feiman-Nemser (2010), is likely to result in pre-service teachers being less informed and less able to form an integrative understanding of their role as teachers, and rather to be individuals who will emulate others or passively taught ways of practice. This might be interpreted as pre-service teachers becoming individuals who consider what one does (as in the present context), rather than why one does what one does.

Previous learning experiences, self-derived beliefs and beliefs derived from general knowledge are also the other sources of beliefs that emerged in the data. Previous learning experiences (positive and negative) are noted to be the second influential source on beliefs. Data suggest that pre-service teachers also form their beliefs according to the characteristics of the previous teachers they liked/disliked, as well as the teaching approaches and techniques they previously liked/disliked as students. They use the teachers they liked as role models and they do not wish to resemble the teachers they disliked. Similarly, the pre-service teachers in the present study also referred from time to time to their previous teachers and previous learning experiences, which shows the influence of these on the formation of their beliefs, which is in line with the findings of various studies (Bailey et al., 1996; Mattheoudakis, 2007; Numrich, 1996; Peacock, 2001). Beliefs derived from self (i.e., believing that every student likes group-work activities because he/she likes it) also seem to appear in the data as in the study of Bailey et al. (1996), which perhaps echoes Richards and Lockhart's (1996) personality factor as playing a role in belief development/formation. Finally, although not frequently, beliefs derived from general knowledge (beliefs which pre-service teachers' viewed as accepted by everyone) also seemed to be influencing their beliefs. 


\section{Implications}

The findings from the present study indicate that the ELT programme itself exerts a powerful influence on forming or shaping pre-service teachers' beliefs. Although this is not the case in other studies (e.g., Altan, 2006; Cabaroglu \& Roberts, 2000; Peacock, 2001), years of heavy emphasis on theories of language teaching and learning seems to influence pre-service teachers' beliefs throughout what is presented in the present ELT programme. This is not only related to heavy emphasis on theory input, but late and limited exposure to practice teaching can also be viewed as factors that inhibit pre-service teachers from developing pedagogical reasoning in the earlier years of the ELT programme. If we take the recent philosophy of teaching and learning into account, that is, to allow teacher candidates to get exposed to theory and practice at the same time with an adequate balance (Korthagen, 2010), the current structure of the ELT programme does not seem to provide this. What is more, the picture deriving from the study addresses a group of learners who passively receives the input provided to them. This is not to say that their beliefs would have been different if they had been exposed to practice more, but it would be possible that they would have had a more critical perspective on the beliefs they held. Although there are many studies in the literature indicating the influence of teacher education on teacher beliefs from an optimistic perspective, it seems that only few of these studies consider the programme nature when evaluating beliefs (i.e., Cabaroglu \& Roberts, 2000). It is thus essential, at least from the present study's perspective, to consider programme nature while evaluating beliefs, and make a distinction between the different teacher-education programmes discussed in the literature. For programmes of this kind, consideration of implications such as balancing theory and practice and exploring student teachers to practice earlier seem to be crucial, for the sake of healthier teacher education.

\section{References}

Allen, L. Q. (2002). Teachers' Pedagogical Beliefs and the Standards for Foreign Language Learning. Foreign Language Annals, 35, 518-529. http://dx.doi.org/10.1111/j.1944-9720.2002.tb02720.x

Altan, M. Z. (2006). Beliefs about language learning of foreign language-major university students. Australian Journal of Teacher Education, 31(2), 45-52. http://dx.doi.org/10.14221/ajte.2006v31n2.5

Bailey, K. M. et al. (1996). The language learner's autobiography: Examining the "apprenticeship of observation". In D. Freeman, \& J. C. Richards (Eds.), Teacher Learning in Language Teaching (pp. 11-29). New York: Cambridge University Press.

Borg, S. (1998). Teachers' pedagogical systems and grammar teaching: A qualitative study. TESOL Quarterly, 32(1), 9-38. http://dx.doi.org/10.2307/3587900

Borg, S. (2003). Teacher cognition in language teaching: A review of research on what language teachers think, know, believe, and do. Language Teaching, 36(2), 81-109. http://dx.doi.org/10.1017/s0261444803001903

Borg, S. (2006). Teacher cognition and language education. London, UK: Continuum.

Brown, J., \& McGannon, S. (1998). What do I know about language learning? The story of the beginning teacher. 23rd ALAA Congress. Retrieved 17 February, 2006, from http://www.cltr.uq.edu.au/alsaa/proceed/bro-mcgan.html.

Busch, D. (2010). Pre-service teacher beliefs about language learning: The second language acquisition course as an agent for change. Language Teaching Research, 14(3), 318-337. http://dx.doi.org/10.1177/1362168810365239

Cabaroglu, N., \& Roberts, J. (2000). Development in student teachers' pre-existing beliefs during a 1-year PGCE programme. System, 28(3), 387-402. http://dx.doi.org/10.1016/s0346-251x(00)00019-1

Crookes, G. (1997). What influences what and how second language teachers teach? Modern Language Journal, 81, 67-79. http://dx.doi.org/10.2307/329161

Da Silva, M. (2005). Constructing the teaching process from inside out: How pre-service teachers make sense of their perceptions of the teaching of the four skills. TESL-EJ, 9(2), 1-9.

Erkmen, B. (2010). Non-native novice EFL teachers' beliefs about teaching and learning (Unpublished doctoral dissertation). University of Notthingham, England.

Farrell, T. S. C. (1999). The reflective assignment: Unlocking pre-service teachers' beliefs on grammar teaching. RELC Journal, 30(2), 1-17. http://dx.doi.org/10.1177/003368829903000201

Farrell, T. S. C. (2001). English language teacher socialisation during the practicum. Prospect, 16, 49-62.

Feiman-Nemser, S. (2011). The prospect legacy. The New Educator, 7(3), 196-199. 
http://dx.doi.org/10.1080/1547688x.2011.593985

Isikoglu, N., Basturk, R., \& Karaca, F. (2009). Assessing in-service teachers' instructional beliefs about student-centered education: A Turkish perspective. Teaching and Teacher Education, 25(2), 350-356. http://dx.doi.org/10.1016/j.tate.2008.08.004

Johnson, K. E., \& Golombek, P. R. (2003). Teachers' narrative inquiry as professional development. New York: Cambridge University Press.

Korthagen, F. A. J. (2010). Situated learning theory and the pedagogy of teacher education: Towards and integrative view of teacher behavior and teacher learning. Teaching and Teacher Education, 26(1), 98-106. http://dx.doi.org/10.1016/j.tate.2009.05.001

Lihua, Y. (2010). A study of ethnic Mongolian university EFL teachers' beliefs and decision making. Chinese Journal of Applied Linguistics, 33(2), 60-75.

Lortie, D. (1975). Schoolteacher: A Sociological Study. Chicago: University of Chicago Press.

Mansfield, C. F., \& Volet, S. E. (2010). Developing beliefs about classroom motivation: Journeys of preservice teachers. Teaching and Teacher Education, 26(7), 1404-1415. http://dx.doi.org/10.1016/j.tate.2010.04.005

Mattheoudakis, M. (2007). Tracking changes in pre-service EFL teacher beliefs in Greece: A longitudinal study. Teaching and Teacher Education, 23(8), 1272-1288. http://dx.doi.org/10.1016/j.tate.2006.06.001

Miles, M. B., \& Huberman, A. M. (1994). Qualitative Data Analysis (2nd ed.). Thousand Oaks, CA: Sage Publications.

Ng, W., Nicholas, H., \& Williams, A. (2010). School experience influences on pre-service teachers' evolving beliefs about effective teaching. Teaching and Teacher Education, 26(2), 278-289. http://dx.doi.org/10.1016/j.tate.2009.03.010

Numrich, C. (1996). On becoming a language teacher: Insights from diary studies. TESOL Quarterly, 30(1), 131-153. http://dx.doi.org/10.2307/3587610

Ong'Ondo, O. C., \& Borg, S. (2011). "We teach plastic lessons to please them"-The influence of supervision on the practice of English language student teachers in Kenya. Language Teaching Research, 14(3), 509-528. http://dx.doi.org/10.1177/1362168811412881

Pajares, M. (1992). Teachers' beliefs and educational research: Cleaning up a messy construct. Review of Educational Research, 62, 307-332. http://dx.doi.org/10.3102/00346543062003307

Patton, M. Q. (2002). Qualitative research \& evaluation methods (3rd ed.). Thousand Oaks, CA: Sage.

Peacock, M. (2001). Pre-service ESL teachers' beliefs about second language learning: A longitudinal study. System, 29(2), 177-195. http://dx.doi.org/10.1016/s0346-251x(01)00010-0

Phipps, S., \& Borg, S. (2009). Exploring tensions between teachers' grammar teaching beliefs and practices. System, 37(3), 380-390. http://dx.doi.org/10.1016/j.system.2009.03.002

Richards, J. C., \& Lockhart, C. (1996). Reflective teaching in second language classrooms. Cambridge, UK: Cambridge University Press.

Urmston, A. (2003). Learning to teach English in Hong Kong: The opinions of teachers in training. Language and Education, 17, 112-137. http://dx.doi.org/10.1080/09500780308666843

Warford, M., \& Reeves, J. (2003). Falling into it: Novice TESOL teacher thinking. Teachers and Teaching: Theory and Practice, 9(1), 47-65. http://dx.doi.org/10.1080/1354060032000049904

Wong, M. S. L. (2010). Beliefs about language learning: A study of Malaysian pre-service teachers. RELC Journal, 41, 123-136. http://dx.doi.org/10.1177/0033688210373124

Yang, N. D. (2000). What do prospective teachers think about teaching English to children? In Selected Papers from the Ninth International Symposium on English Teaching (pp. 556-565). Taipei, Taiwan: Crane Publishing Co.

Zheng, H. (2012). Dilemmas in teacher development in the Chinese EFL context. Journal of Cambridge Studies, 7(2), 2-16. 


\section{Copyrights}

Copyright for this article is retained by the author(s), with first publication rights granted to the journal.

This is an open-access article distributed under the terms and conditions of the Creative Commons Attribution license (http://creativecommons.org/licenses/by/3.0/). 